\title{
ALEXANDR ČUBARJAN A SOVĚTSKÉ DĚDICTVÍ SOUČASNÉ RUSKÉ HISTORIOGRAFIE
}

DANIELA KOLENOVSKÁ

\begin{abstract}
Alexander Chubaryan and the Soviet-Era Legacy in Contemporary Russian Historiography

The knowledge of Russia’s Soviet past has advanced following the partial opening of archives in early 1990s. Ever since, the Russian historical discourse has developed in three main areas: politics, science, and education. The article assesses the role the professional historians are assigned to in the shaping of the historical memory in Putin's Russia and in constructing the new Russian identity through the redefining of Russia's Soviet past. It exemplifies this process through a biographical study of Alexander Chubaryan, the regime's prominent historian.
\end{abstract}

Keywords: Russia, Soviet Union, foreign policy, historiography, politics of memory, politics of history DOI: $10.14712 / 23363231.2015 .77$

\section{Úvod}

Ruskou historiografii provázely v posledním dvacetiletí zásadní změny související s rozkladem marxisticko-leninského paradigmatu i se zhroucením země, která jej dlouhá léta prosazovala. S jistou nadsázkou lze říci, že poznání hloubky a závažnosti navazujících procesů usnadní srovnání s dlouhodobými dopady zániku tradičních koloniálních impérií, jakkoliv zde pochopitelně všechny paralely nutně zaostávají. Pokud jde o historickou vědu a referování o minulosti, provázela rozpad Sovětského svazu a jeho evropského spojeneckého systému provincionalizace jednotlivých národních historiografií a snaha vymanit se s pomocí západních vědců $\mathrm{z}$ teoretického i metodologického vakua. Vědci ruku v ruce s obměněnými politickými reprezentacemi také prověřovali dřívější ideologizovanou sociální vědou vytvořené závěry a hledali nový vztah k národním dějinám. 
V této studii se pokouším postihnout proměnu podílu ruské historiografie na modelování vztahu ruské veřejnosti k sovětské minulosti. Stranou přitom ponechávám rozbor vztahu politiky paměti $\mathrm{k}$ dějinám resp. $\mathrm{k}$ souboru výsledků kritického historického poznání. ${ }^{1}$ Teoreticky se opírám o pojetí politiky paměti jako jednoho ze způsobů vytváření sociální a politické identity. ${ }^{2}$ Proměnu ruské sociální paměti přitom chápu jako součást vytváření ruské politické identity, které probíhá jako střednědobý proces za přispění moderních technických prostředků a různých institucionalizovaných aktérů. ${ }^{3} \mathrm{~S}$ ohledem na omezení daná rozsahem této dílčí práce sleduji po úvodním stručném představení základních prvků proměny historického diskurzu v postsovětském Rusku její průběh pomocí klíčové studie. Zaměřuji se na logiku jednání ve vrcholné akademické funkci nejdéle působícího představitele centrálního ruského historického pracoviště, Alexandra Čubarjana. Vědecké poznání bylo sice v konkrétních specializovaných tématech posunuto dále jinými ruskými historiky, Čubarjan však spoluvytvářel zázemí jejich výzkumu v průběhu posledních desetiletí. Politiku paměti v Rusku lze jeho prostřednictvím proto sledovat $\mathrm{v}$ potřebné kontinuitě, nikoliv jako záležitost náhlého zvratu. Současně Čubarjana ze skupiny podobně kariérně zaměřených ruských historiků (např. A. N. Sacharov, G. N. Sevostjanov, $\mathrm{V}$. K. Volkov) vyčleňuje jeho výjimečný vliv v zahraničí, který umožňuje postihnout také důležitý mezinárodní rozměr proměny ruské politiky paměti.

Základním zdrojem úvodní obecné části studie jsou tři sborníky úvah ruských historiků nad aktuálním stavem a pozicí jejich oboru v Rusku vydané postupně v letech 1996, 2003 a 2011 moskevským nakladatelstvím AIRO-XX resp. AIRO-XXI. ${ }^{4} \mathrm{~V}$ části popisující Čubarjanovo profesní působení se opírám o rozbor jeho vlastních odborných textů. Protože většina $z$ nich vlivem archivní revoluce na konci 20. století zastarala, zabývám se podrobněji dvěma nejvýraznějšími tituly. Prvním je kniha Evropská idea v historii, ${ }^{5}$ která je nejvíce

1 Miroslav Hroch, „Pamět a historické vědomí očima historika“, in Kolektivní pamět. K teoretickým otázkám, ed. Nicolas Maslowski a Jiří Šubrt (Praha: Karolinum, 2009), 46-65.

2 Peter Burke, Variety kulturních dějin (Brno: CDK, 2006), 50-66.

3 Peter Burke, Společnost a vědění II. Od Encyklopedie k Wikipedii (Praha: Karolinum, 2013), 301-302.

4 Gennadij Bordjugov, ed., Istoričeskije issledovanija v Rossii: Tendencii poslednich let (Moskva: AIRO-XX, 1996); Gennadij Bordjugov, ed., Istoričeskije issledovanija. II. Sem' let spustja (Moskva: AIRO-XXI, 2003); Gennadij Bordjugov, ed., Istoričeskije issledovanija v Rossii. III. Pjatnadcat' let spustja (Moskva: AIRO-XXI, 2011).

5 Aleksandr Čubar'jan, Jevropejskaja ideja v istorii. Problemy vojny i mira (Moskva: Meždunarodnyje otnošenija, 1987). Německy Alexander Tschubarjan, Europakonzepte von Napoleon bis zur Gegenwart. Ein Beitrag aus Moskau (Berlin: Quintessenz Verlag, 1992, 1998). Anglicky Alexander Tchoubarian, The European Idea in History in the Nineteenth and Twentieth Centuries: A View From Moscow (London: Routledge, 1994, 2013). Francouzsky práce vyšla s předmluvou ekonoma Jacquese Sapira jako Alexandre Tchoubarian, La Russie et l'idée européeenne (Paris: Éditions des Syrtes, 2009). 
překládaným Čubarjanovým textem; druhým je ruskými historiky nejvíce ceněná Čubarjanova práce z poslední doby, kniha Počátek tragédie. ${ }^{6}$ Mimo odborné texty sleduji také Čubarjanova veřejná vystoupení v tisku a v televizi, jejichž přehled uvádí Čubarjanův domovský Institut všeobecných dějin Ruské akademie věd na svých internetových stránkách. ${ }^{7}$ Tamtéž je možno získat základní informace o Čubarjanově kariéře. ${ }^{8}$ Jako důležitý komparativní materiál ve vztahu k aktuální ruské koncepci historického vzdělávání, prosazované Čubarjanem, ${ }^{9}$ pak této studii posloužil soubor textů ruských činitelů podílejících se na první postsovětské reformě ruského historického vzdělávání, který vyšel díky Gabrielu Gorodeckému v Izraeli. ${ }^{10}$

Rusko jako nástupnický stát Sovětského svazu dlouho váhalo, jak se sovětským dědictvím naložit. Komunistická strana zůstala vlivnou politickou silou. Postsovětská elita se v náročné situaci projevila jako málo efektivní. Ekonomické priority, které před sebe primárně stavěla, se jí nedařilo naplňovat. Sociologové Aleksandr Galkin a Jurij Krasin hledali důvody tohoto stavu v prudké snaze nových mocných vykořenit $\mathrm{z}$ ruské společnosti kolektivismus a podř́zenost ideji jednotného státu, aniž bylo předem dosaženo konsensu o novém společenském rámci. ${ }^{11}$ Politoložka Oksana Gaman-Golutvina označila za prŕćcinu takového selhání způsob, jakým Rusko přistupovalo k vlastní modernizaci. Podle její historické analýzy byl proces modernizace $\mathrm{v}$ Rusku tradičně více než jeho vnitřními hospodářskými potřebami rrízen vnějšími impulzy a převládal při něm mobilizační charakter výběru elit. Taková personální politika podle Gaman-Golutvinové vyvolávala nízkou vnitřní soudržnost ruských elit, jejich zaměření na ekonomické cíle i přehlíživý vztah k jiným prioritám. ${ }^{12}$ Ruská politika paměti se tedy navzdory snaze dřívějších disidentů měnila jen

${ }^{6}$ Aleksandr Čubar'jan, Kanun tragedii. Stalin i meždunarodnyj krizis. Sentjabr' 1939 - ijun' 1941 goda (Moskva: Nauka, 2008).

7 SMI o nas. Metka - A. O. Čubar'jan, Institut vseobščej istorii Rossijskoj Akademii Nauk, http://igh .ru/smi/tag/\%D0\%90.\%D0\%9E.\%20\%D0\%A7\%D1\%83\%D0\%B1\%D0\%B0\%D1\%80\%D1\%8C\%D1 $\% 8 \mathrm{~F} \% \mathrm{D} 0 \% \mathrm{BD} /$.

${ }^{8}$ A. O. Čubar'jan, Institut vseobščej istorii Rossijskoj Akademii Nauk, http://igh.ru/book/authors /chubaryan-alexander-oganovich/; Viz též Kto jest' kto - Čubar'jan Aleksandr Oganovič, Rossijskij gosudarstvennyj gumannitarnyj universitet, www.rsuh.ru/who_is_who/detail.php?ID=5467.

9 Koncepcija novogo učebno-metodičeskogo kompleksa po otečestvennoj istorii. Ke stažení je text k dispozici mj. na stránkách Ruské historické společnosti http://rushistory.org/?page_id=1219.

${ }^{10}$ Např. J. Jegorov, V. Bordovskij nebo P. Baranov in Vera Kaplan, Pinchas Agmon a Liubov Ermolaeva, The Teaching of History in Contemporary Russia / Prepodavanie istorii v Rossii (Tel Aviv: Cummings Center, 1999).

${ }^{11}$ Aleksandr Galkin a Jurij Krasin, Rossija: Quo vadis? (Moskva: Izd-vo Instituta sociologii RAN, 2003).

12 Oksana Gaman-Golutvina, Političeskije elity Rossii. Vechi istoričeskoj evoljucii (Moskva: ROSSPEN, 2006). 
velmi pomalu. ${ }^{13}$ Částečné zpř́stupnění domácích i zahraničních archivních fondů ovšem přineslo významný podnět k diskusím. Ruský veřejný prostor zaplnily debaty o minulosti, které vedle úmyslu poctivěji a šíreji nahlédnout dějiny charakterizovala také intenzivní snaha definovat pro Rusko správnou cestu do budoucnosti. Své mimořádné pozice $\mathrm{v}$ ruské společnosti se nevzdávali spisovatelé a ve svých dílech nabízeli vlastní vize minulosti i př́tomnosti. Společnost se vracela $\mathrm{k}$ argumentům západniků, slavjanofilů nebo eurasijců. Důležitým tématem se stala také geopolitika. Tyto myšlenkové směry poskytly základ dalšímu názorovému štěpení. Ke slovu se dostaly úvahy o ruské dějinné filozofii rozvíjené po Chruščovem iniciovaném uvolnění především v sovětském disentu (A. Achijezer, I. Ogurcov, nebo N. Osipov). Zatímco pro liberály byl jasným cílem demokratický a právní stát, konzervativní filozofie rozvíjela představy o existenci specifické historické mise Ruska a ruské pravoslavné civilizace. Konzervativci odmítli rozpad Sovětského svazu jako nepřirozený rozklad tisíciletého útvaru a v tomto sovětském patriotismu se setkali s komunisty. Sdíleli s nimi také odmítavý postoj k Západu (nebo eurocentrismu) a globalizaci i Gennadijem Zjuganovem artikulovanou úctu ke kolektivním hodnotám uchovaným podle nich $\mathrm{v}$ mimořádném ruském prostředí. ${ }^{14}$

Ruští historici byli v politicky turbulentní době zbaveni povinnosti respektovat ve svých dílech marxistický světový názor a museli se vyrovnat s př́livem informací plynoucích $\mathrm{z}$ otevřených archivů. Část $\mathrm{z}$ nich, označovaná dodatečně jako konzervativci nebo formalisté, u marxistického pohledu na svět setrvala, snažila se aktualizovat předchozí výzkumy a zamýšlela je opravit podle nových dat. Jiné skupiny marxismus odmítly, shromaždovaly informace o dřive zamlčovaných úsecích ruské minulosti a hledaly nové metody, jak je interpretovat. Výsledky zahraniční teorie historické vědy dokázal v kvapném společenském pnutí využít málokdo. Chyběla zahraniční literatura, překlady i znalost cizích jazyků. V př́ípadě oborů, jejichž široké zastoupení $\mathrm{v}$ sovětské vědě souviselo $s$ někdejší spoluprací socialistického tábora, došlo v důsledku jeho rozkladu dokonce ke zúžení kontaktů. ${ }^{15}$ Realita překotně

13 Viz např. Žores Medvedev a Roj Medvedev, Solženicyn i Sacharov. Dva proroka (Moskva: Vremja, 2004); česky vyšlo Roj Medvedev, Stalin a stalinizmus. Historické črty (Bratislava: Obzor, 1990). Viz též Vladimir Bukovskij, Moskevský proces (Praha: Volvox Globator, 2015).

14 Aleksandr Panarin, Politologija. Zapadnaja i Vostočnaja tradicii: učebnik dlja vuzov (Moskva: Knižnyj dom Universitet, 2000). Srov. Gennadij Zjuganov, Global'noje poraboščenije Rossii, ili Globalizacija po-amerikanski (Moskva: Éksmo, 2011).

15 Viz např. Vladimir Volkov, „Rossijskoje slavjanovedenije: včera, segodnja, zavtra. (K 50-letiju Instituta slavjanovedenija i balkanistiki RAN)“, in Institut slavjanovedenija i balkanistiki. 50 let, ed. Je. P. Aksjonova, Ju. V. Bogdanov, M. A. Vasiljev et al. (Moskva: Indrik, 1996), 7-32. Viz též Jurij Afanas'jev, ed., Sovetskaja istoriografija. V 2 kn. (Moskva: Rossijskij gosudarstvennyj gumanitarnyj universitet, 1996); a dále Odd Arne Vestad, Oleg Višlev, Il'ja Gajduk et al., Osmyslenije istorii (Moskva: Prosveščenije, 1996). 
a všestranně se rozvíjející postsovětské společnosti nicméně neposkytla teoretickým úvahám dostatečný čas. Situaci ztěžoval hospodářský propad prvních reforem, proměny institucionálního a finančního zázemí akademické obce i nekoncepční státní politika v oblasti společenských věd a historického vzdělávání. ${ }^{16}$ Negativní dopad na ruskou historiografii měly také zahraniční společenské procesy a hledání nových identit po rozpadu sovětského bloku a Sovětského svazu. Co přijmout ze sovětského nehmotného dědictví za své patřilo $k$ nejpalčivějším problémům. $Z$ pohledu ruské historiografie zejména politici využívali selektivního výkladu minulosti jako prostředku $\mathrm{k}$ podpoře vlastní pozice, a napomohli tak $\mathrm{k}$ militarizaci ruské historické diskuse podle klíče „My versus Oni“. ${ }^{17}$ Tedy dříve než ruští historici mohli absorbovat všechny změny a zvážit význam, jejž mělo pro ruské dějiny sovětské období, vyrostla touto érou nedotčená generace a celkový zájem společnosti o odborný názor na národní dějiny poklesl. Ačkoliv obraz vlastní minulosti a vztah $\mathrm{k}$ němu nadále spoluurčují orientaci Rusů ve světě, historická témata se přesunula více do oficiálních projevů ruských státních představitelů a emotivních mediálních diskusí. Největší spory se přitom vedou o výklad minulosti žijících pamětníků a také o př́běh státu, s nímž se identifikují.

\section{Sovětské dějiny v ruském diskurzu: aktéři, metody}

Počátek sovětských dějin je v dnešním Rusku nejčastěji kladen do roku 1917. Tematicky jde o převážně vnitropolitický prostor otevřený abdikací cara Mikuláše II., který se s výrazným mezníkem stalinismu rozrůstá o obhajobu ruských zájmů v zahraničí. Institucionálně je výzkum uvedeného období zaštítěn univerzitami, systematičtěji pak ústavy Ruské akademie věd a centrálními archivy v Moskvě. Za hlavní pracoviště lze označit Oddělení historicko-filologických věd Ústavu všeobecných dějin Ruské akademie věd (Institut vseobščej istorii RAN). ${ }^{18}$ Sovětským dějinám se věnují také Ústav ruské historie (Institut rossijskoj istorii RAN), Ústav studia Slovanů (Institut slavjanovedenija RAN), Ústav Evropy (Institut Jevropy RAN), Ústav východních studií (Institut vostokovedenija RAN) a Ústav Afriky

16 „Zasedanie naučno-konsul'tativnogo soveta pri istoriko-diplomatičeskom upravlenii Ministerstva inostrannych del SSSR“, Novaja i novejšaja istorija 32, č. 5 (1989): 222-25; „Problemy istoričeskoj nauky“, Novaja i novejšaja istorija 32, č. 6 (1989): 80-88. Srov. „Obščeje sobranije otdelenija istorii RAN“, Novaja i novejšaja istorija 38, č. 5 (1995): 3-7.

17 Alexei Miller a Maria Lipman, eds. The Convolutions of Historical Politics (Budapest: Central European University Press, 2012). Viz též Akademik Aleksandr Čubar'jan: Učebnik, v kotorom Bandera budet gerojem, ne podpišem!, Komsomol'skaja pravda, 5. dubna 2011, http://www.kp.ru /daily/25663/825131/.

18 Webová stránka oddělení http://hist-phil.ru. 
(Institut Afriki RAN). Z archivů jde především o Státní archiv Ruské federace (Gosudarstvennyj archiv Rossijskoj Federacii), Ruský státní archiv politické historie (Rossijskij gosudarstvennyj archiv social'no-političeskoj istorii), Archiv ministerstva zahraničních věcí (Archiv Ministerstva inostrannych del) a Archiv prezidenta Ruské federace (Archiv Prezidenta Rossijskoj Federacii). Z univerzit nelze pak pominout Katedru nové a nejnovější historie Historické fakulty Moskevské státní univerzity (Istoričeskij fakul'tet MGU im. Lomonosova), dále Historicko-archivnický ústav Ruské státní humanitní univerzity (Istoriko-archivnyj institut $R G G U$ ) a Katedru historie a politiky států Evropy a Ameriky Moskevské státní univerzity mezinárodních vztahů $(M G I M O)$. Do výkladu sovětských dějin zasahují i regionální muzea a nevládní organizace, především společnost Memorial (Meždunarodnoje istoriko-prosvetitel'skoje, pravozaščitnoje i blagotvoritel'noje obščestvo „Memorial“), Fond Gorbačova (Meždunarodnyj fond social'no-ekonomičeskich i politologičeskich issledovanij, Gorbačev-Fond) a centrum Carnegie (Moskovskij Centr Karnegi). ${ }^{19}$ Mimořádnou pozici si díky své nakladatelské činnosti získala také nevládní organizace Mezinárodní fond Demokracie, kterou řídil dřívější Gorbačovův blízký spolupracovník Alexandr Jakovlev. ${ }^{20}$

Z metodického hlediska našel dnes reálný ruský historický výzkum sovětských dějin své útočiště v pozitivistické archivní práci, specializoval se a přestal aspirovat na vyřešení ruské budoucnosti. Ti, kdo ještě seriózně usilují o nalezení nějakého obecnějšího konceptu ruských dějin, varují před př́lišným důrazem na politicko-mocenskou stránku minulosti a vytvářením líbivých historických paralel a vedle širších společenských procesů zvažují také nové metodologické postupy. V 90. letech minulého století nosné modernizační schéma cyklického pohybu Ruska mezi reformami a kontrareformami dnes někteří z nich považují za vyčerpané, mimo jiné z toho důvodu, že ideál 19. století, Západ, obecně ztratil ve 21. století na přitažlivosti a pro současné ruské západniky je stále tě̌̌ší nalézat v něm inspiraci. ${ }^{21}$ Přesto právě zmíněné nevládní organizace myšlenku demokratického a právního státu podporují. Podobně při podpoře liberalismu vystupuje rovněž nakladatelství Fondu Liberální mise (Fond Liberal'naja missija), vedeného ekonomem Jevgenijem Jasinem. Také akademičtí liberálové publikují své texty nadále. Již třetího vydání se dočkala práce Ruská historie: konec nebo nový začátek?, která čerpá z Achijezerova konceptu ruských dějin. Ten vychází z kulturně-historického přístupu

19 Webové stránky zmíněných organizací v pořadí uvedeném v textu: http://memorial.ru, www.gorby.ru, www.carnegie.ru.

20 Alexandr Jakovlev, Rusko plné kř́žư (Brno: Doplněk, 2008).

${ }^{21}$ Viz např. Aleksej Iljič Miller, Imperija Romanovych i nacionalizm: ésse po metodologii istoričeskogo issledovanija (Moskva: Novoje literaturnoje obozrenije, 2006). 
a ruskou společnost nahlíží jako odsouzenou k cyklickému pohybu mezi násilnou diktaturou a krátkými momenty pozitivního celospolečenského vření do doby, než splní dříve ignorované civilizační úkoly a dosáhne v Rusku ideálu sociálního konsensu. $^{22}$

Č́st současných ruských historiků nahradila zmíněné modernizační paradigma na přelomu století po vzoru Samuela Huntingtona tzv. civilizačním př́stupem. ${ }^{23}$ V př́padě ruských dějin vyzdvihují vliv př́rodních podmínek na formování jedinečné povahy ruské společnosti. ${ }^{24}$ Ty jsou výhodné při definování historické identity nového Ruska nejen ukotvením $\mathrm{v}$ nezpochybnitelných a snadno měřitelných výsledcích př́rodních věd, ale také proto, že zdůvodňují nutnost chápat ruský národ v politickém smyslu slova a etnické záležitosti vnímat jako jeho dílčí podotázky. ${ }^{25}$ Diferencovaný př́istup k národnostem je současně blízký výše zmíněné konzervativní filozofii, která Rusko vnímá jako sociální a politický protipól liberální demokracie, přičemž dřívější monarchismus nahrazuje etatistickým konceptem silné centrální prezidentské vlády. ${ }^{26}$ Ke konzervativnímu uvažování o ruských dějinách směřuje současné ruské teoretiky vývoje ruského prostoru také Mackinderova teorie z roku 1904. Tento směr uvažování kombinuje myšlenku Heartlandu s některými názory ruských meziválečných eurasijců, dějiny považuje za jen málo podstatné a akceptuje z nich převážně pouze autoritu pravoslaví. Jeho ústřední promotér, Alexandr Dugin, vyzývá ke konzervativní revoluci. Tvrdí, že současná Ruská federace je ahistorický nepřirozený útvar, který bezpečnostní a ekonomické zákony nutně směřují k dokonalejší formě, $k$ vytvoření Nového eurasijského impéria. ${ }^{27}$

Součástí ruského odborného historického diskurzu se staly také debaty o školské výuce. Zpočátku mezery v dějepisu, tzn. bílá místa (belyje pjatna), pomáhali zaplňovat někdejší disidenti a domácí i zahraniční akademici. ${ }^{28}$ Debata o nutných

${ }^{22}$ V prvním vydání vyšlo jako Aleksandr Achijezer a Igor' Kljamkin, Istorija Rossiji: konec ili novoje načalo? (Moskva: Novoje izdatel'stvo, 2005).

23 Samuel Huntington, Střet civilizací. Boj kultur a proměna světového řádu (Praha: Rybka, 2001), 158-63.

${ }^{24}$ Klasická interpretace vlivu místních podmínek na ruské společenské zřízení v češtině viz Vasilij Kluječevskij, Ruské dějiny. Díl I. (Praha: Minařík, 1927), 45-80.

25 Viz např. Leonid Milov, ed. Istorija Rossii s drevnejšich vremen do konca XVII veka (Moskva: Éksmo, 2006); Andrej Zubov, ed. Dějiny Ruska 20. století. I. díl. 1894-1939 (Praha: Argo, 2014), 117-37.

${ }^{26}$ Aleksandr Panarin, Revanš istorii (Moskva: Logos, 1998).

27 Aleksandr Dugin, Osnovy geopolitiki. Geopolitičeskoje buduščeje Rossii (Moskva: Arktogeja, 1997).

28 Situaci odrážela i skutečnost, že ruské dějiny 19. a 20. století byly na doporučení ministerstva vědy na ruských vysokých školách vyučovány od roku 1992 podle překladu učebnice francouzského historika ruského původu Nicolase Wertha. Viz Nikolas Vert, Istorija Sovetskogo gosudarstva. 1900-1991. 2-je izdanije (Moskva: Ves' Mir, 1998). Původní vydání Nicolas Werth, Histoire de l'Union Soviétique: De l'Empire russe à la Communauté des Etats indépendants (Paris: Presses Universitaires de France, 1990). 
změnách obsahové stránky výuky dějepisu nacházela dokonce pravidelný ohlas v akademickém historickém tisku. Když v polovině devadesátých let vznikly první široce respektované učebnice, pozbyly obsahové otázky výuky sovětských dějin na naléhavosti. Pozornost historiků se obrátila $\mathrm{k}$ archivům a učitelé se zaměřili na zlepšování pedagogických metod. Stát, ovládaný jedinou politickou stranou prezidenta Putina, se ovšem do necentralizovaného připomínání minulosti rozhodl zasáhnout. Koncem roku 2003 byla zveřejněna Národní doktrína vzdělávání v Ruské federaci, která stanovila priority školského systému. Z hlediska historie jsou zásadní dva první body: 1) zajistit historickou návaznost generací, zachování, šíření a rozvoj národní kultury a kulturního dědictví Ruska; a 2) vychovávat ruské patrioty v demokratickém duchu s ohledem na současný stav vědy. Školy se přitom měly stát místními vzdělávacími centry. Po roce 2005, kdy orientace prvního Putinova prezidentského období na pragmatismus a silnou technokratickou centrální moc nepřinesla očekávaný konsolidační efekt, byla tato doktrína netrpělivě rozšiřrena o snahu vytvořit reprezentativní výklad národních dějin.

Někteří odborníci se změnám bránili. Nejprve oponovali státem do školské výuky prosazovanému standardu humanitních věd a zpochybňovali obsah s ním spojeného kulturně-historického základu. Jejich kritice se nevyhnul ani způsob, jakým od roku 2005 připravený systém jednotných státních zkoušek testoval znalosti dějepisu. ${ }^{29} \mathrm{~A}$ konečně do třetice protestovali proti kontroverzním titulům, o něž se rozšiŕilo spektrum učebnic doporučovaných ruským ministerstvem školství k výuce dějin. Mimořádné protesty vzbudily především nové učebnice spojené se jménem do té doby prakticky neznámého Alexandra Filippova určené pro závěrečné ročníky ruských základních škol a jejich učitele. ${ }^{30} \mathrm{Za} \mathrm{jejich} \mathrm{hlavní} \mathrm{nedosta-}$ tek bylo považováno, že výchovu k patriotismu nahrazují výchovou k nekritické loajalitě vůči autoritám a Putinův politický koncept „suverénní demokracie“ prezentují jako objektivně ukotvený popis skutečného politického režimu v Rusku. ${ }^{31}$ Podobné diskuse byly vedeny také nad publikacemi profesorů Moskevské státní univerzity Alexandra Barsenkova a Alexandra Vdovina, jež z matematiky převzatá teorie synergie dovedla mimo zmíněné problematické závěry také $k$ antisemitsky

29 Viz interview Olgy Daškovské s Alexandrem Čubarjanem Istorija ne dolžna byt'založnicej politiki, Pervoje sentjabrja, č. 8 (2011), http://ps.1september.ru/article.php?ID=201100803.

30 Aleksandr Filippov, Novejšaja istorija Rossii 1945-2006 gg. Kniga dlja učitelja (Moskva: Prosveščenije, 2007); Aleksandr Danilov, Anatolij Utkin a Aleksandr Filippov, eds., Istorija Rossii. 1945-2008 gg.: 11 klass: Učebnik dlja učaščichsja obščeobrazovatel'nych učreždenij. Izd. 2-oje (Moskva: Prosveščenije, 2008).

31 Alexei Miller, „Russia: Power and History“, in Engaging History: The Problems and Politics of History in Russia, ed. Samuel Green, Maria Lipman a Andrey Ryabov (Moscow: Carnegie Moscow Center, 2011), 19-20. 
vnímaným výrokům. Na rozdíl od Filippova však uznávaní profesoři nalezli větší pochopení kolegů. Zvláštní komise Moskevské státní univerzity, svolaná k prošetření jejich př́ípadu, sice pro zjištěné nedostatky omezila užívání jejich publikací ve výuce, zároveň se však ohradila proti omezování akademické svobody a možnosti formulovat vědecké názory. 32

Stát ovšem v uplatňování normativních nástrojů vůči historické vědě vytrval. Prezident Medveděv vydal v květnu 2009 dekret, kterým zř́dil komisi proti falzifikaci historie, která by poškozovala ruské zájmy. Návazně vznikl během tř́ dní v akademii věd seznam jednotlivců a organizací dopouštějících se podobného pokřivování historie nebo šírících takový výklad dějin. ${ }^{33}$ Také v důsledku této ostrakizace vybraných vědců se veřejný diskurz o ruských dějinách povětšinou rozvijí mimo solidní vědecká zjištění, často v talk-show na televizních obrazovkách. ${ }^{34} \mathrm{Na}$ rozdíl od převratných 90 . let se na něm jako historici nejvíce podílejí mediálně zdatní autoři interpretačních textů, kteří neusilují o odborný ani zahraniční respekt ke svým názorům a tíhnou k nacionalistickým klišé. Je zřejmé, že podstatnou silou v tomto procesu je tlak Vladimira Putina na vytvoření pozitivní ruské národní identity. Někteří historici už jeho éru svými texty dokonce zařadili mezi zásadní události ruských dějin, hlásí se k němu citacemi a i jinak dávají najevo, že jejich práce je shora schvalována. Jsou proto vnímáni jako kremelští (dvorní) autoři, kteří namísto skutečného výzkumu profitují (kariérně i materiálně) $\mathrm{z}$ politizace historie a $\mathrm{z}$ účasti na prosazování historické politiky nové ruské elity, potažmo z podílu na šírení nové ideologie suverénní demokracie. ${ }^{35}$ Ale samozřejmě nejde jen o Putina. Jeho slovní i symbolická vyjádření k minulosti, stejně jako jeho aktivity na poli školní výuky, vycházejí vstříc ruské společnosti doufající podle renomovaných výzkumů v proměnu své vlasti v znovu obávanou velmoc. Výzkum stereotypů, které si ruská společnost zachovala ze sovětských dob, naznačuje, že její rutinní každodenní chování a myšlení, i často pouze deklaratorní vztah k novým pravidlům a právům, podporují dominantní roli státu v mnoha oblastech veřejného života, historický diskurz nevyjímaje. ${ }^{36}$

32 Po povodu obščestvennogo obsuždenija učebnogo posobija A. S. Barsenkova i A. I. Vdovina Istorija Rossii 1917-2009 (Moskva: Aspekt Press, 2010), Moskovskij Gosudarstvennyj Universitet imeni M. V. Lomonosova, Istoričeskij fakul'tet, http://www.hist.msu.ru/Science/DISKUS/2010/index.html.

33 Miller, „Russia: Power and History“, 19-22.

34 Ze specializovaných pořadů viz nap̌r. projekt Imja Rossija (TV Rossija) z roku 2008 nebo projekt Sud vremeni (TV 5-tyj kanal) běžící v letech 2010 a 2011.

35 Více viz Bordjugov, ed. Istoričeskije issledovanija v Rossii. Tom III, 10, 17-18.

${ }^{36}$ Leonid Borodkin, Chajs Kessler, Andrej Sokolov, eds., Sovetskoje nasledstvo. Otraženije prošlogo $v$ social'nych i ékonomičeskich praktikach sovremennoj Rossii (Moskva: ROSSPEN, 2010). 


\section{Historik suverénní demokracie}

K dnešní situaci ruské historiografie patří vedle významného regulačního působení státních normativů také snaha vrcholných ruských politiků určovat mezi historiky autority, které podporují integritě státu prospívající „správný“ výklad dějin novým generacím. Dlouhodobě a s narůstající intenzitou se na historické politice současného Ruska podílí Alexandr Čubarjan. Když loni v červnu přebíral v kremelském Georgijevském sále státní cenu udělovanou ruským prezidentem ve výroční den vyhlášení suverenity Ruské federace, hlasatel během 45 sekund vyzdvihl jeho prýnos ke zkoumání rusko-evropských vztahů v 19. i 20. století, zásluhy o šírení humanitního vzdělání, jeho snahu přizpůsobit stř̌edoškolskou a vysokoškolskou výuku historie jednotnému státnímu standardu a konečně práci na ruské akademické encyklopedii. Sám Čubarjan pak skromně označil své ocenění za doklad uznání významu humanitních věd ze strany státní moci a důkaz důležitosti historického vědění pro rozvoj ruské identity a kultury. ${ }^{37}$

Soudě podle dalších tří vysokých státních vyznamenání, udělených Čubarjanovi v letech 2006, 2010 a 2011, uznání jeho práce ruskými úřady skutečně roste. Navzdory tomu, že Čubarjanova bibliografie obsahuje přes 350 titulů a jeho názory se často objevují i v ruském denním tisku, projevili však ruští historici v poslední době oficiálně respekt $k$ Čubarjanově vlastní vědecké publikaci jen jednou, když mu v roce 2009 udělili Tarleho cenu za knihu Počátek tragédie. ${ }^{38}$ Pomineme-li Čubarjanovy editorské počiny a stručné předmluvy k několika pracím jeho kolegů, ${ }^{39}$ překlady jeho původních textů do jiných jazyků se omezují na Čubarjanův výklad ruského pohledu na myšlenku jednotné Evropy. Také v zahraničí se tak třiaosmdesátiletý ruský akademik těší úctě více pro své organizační kompetence

37 Záznam ceremoniálu předávání Státní ceny Ruské federace z 12. června 2014 na oficiálních stránkách Kremlu www.news.kremlin.ru/video/2643.

38 Čubar'jan, Kanun tragedii.

39 Mikhail Narinski, Elisabeth Du Réau, Georges-Henri Soutou, Alexandre Tchoubarian, eds. La France et l'URSS dans l'Europe des années 20 (Paris: Presses de l'Université de Paris-Sorbonne, 2000); Alexander O. Chubaryan a Harold Shukman, eds., Stalin and the Soviet-Finnish war 1939-40 (London: Frank Cass, 2002); Mikhail Narinski, Elisabeth Du Réau, Georges-Henri Soutou, Alexandre Tchoubarian a Christophe Réveillard, eds., La France et l'URSS dans l'Europe des années 30 (Paris: Presses de l'Université de Paris-Sorbonne, 2005); Stefan Karner a Barbara Stelzl-Marx, eds., Die Rote Armee in Österreich: Sowjetische Besatzung 1945-1955 (Köln: Böhlau, 2005); Stefan Karner, Natalja G. Tomilina, Alexander Tschubarjan, Günter Bischof a Viktor V. Ishchenko, eds., Prager Frühling. Das internationale Krisenjahr 1968 (Köln: Böhlau, 2008); Stefan Karner, Natalja G. Tomilina, Alexander Tschubarjan, Günter Bischof, Viktor V. Ishchenko, eds., Der Wiener Gipfel 1961: Kennedy - Chruschtschow (Innsbruck: Studienverlag, 2011); Helmut Altrichter, Viktor Ischtschenko, Horst Möller a Aleksandr Tschubarjan, eds., Deutschland - Russland: Das 20. Jahrhundert (München: Oldenbourg Wissenschaftsverlag, 2013). 
než pro vědecké teze. Postupně to demonstrovalo jeho vyznamenání francouzským, německým a vatikánským státním řádem.

\section{Vědecká činnost}

Alexandr Čubarjan spojil po absolutoriu na katedře sovětských dějin historické fakulty Moskevské státní univerzity v roce 1955 svůj profesní život s Historickým ústavem moskevské Akademie věd, účastnil se jeho výzkumů a zapojil se za něj také do mezinárodní spolupráce historiků. Přestože dlouhodobě vystupuje v bezpočtu různých veřejných i vědeckých rolí, od roku 1988 je právě funkce ředitele Ústavu všeobecných dějin Ruské akademie věd jeho klíčovou pozicí.

Badatelsky se od počátku specializoval na sovětskou zahraniční politiku. Nejprve svůj zájem zaměřil na okolnosti uzavření Brestlitevského míru a leninskou diplomacii. Mezi jeho hlavní teze té doby patřilo konstatování, že leninské principy tvoří základ úsilí o mírovou koexistenci politicky odlišných režimů, jsou garancí boje za mír a obranou proti sektářùm. Lenin podle něho chápal, že pro zajištění potřeb socialismu byla existence sovětského státu nutná. Dekretem o míru byl podle Čubarjana zahájen trvalý sovětský boj za mír na zemi a Moskva začala řešit problémy celého lidstva. Systematicky postupovala $\mathrm{k}$ nesnadnému Brestlitevskému míru, aby přes očekávání a úsilí kapitalistů z Dohody zajistila sovětskému Rusku alespoň minimální prostor k přežití. Sovětská mírová politika musela podle Čubarjana nalézt způsob, který by umožnil koexistenci dvou různých politických systémů v praxi. Směřovala proto logicky k Janovu, Ženevě a Východnímu paktu. Realisticky přitom usilovala o odzbrojení, obchodní spolupráci i rovnoprávnost všech zemí na mezinárodní scéně. ${ }^{40}$ Tyto teze odpovídaly tehdejší sovětské zahraniční strategii a soulad jeho vědeckých závěrů s praktikovanou politikou zajistil Čubarjanovi od roku 1966 místo přednášejícího na Diplomatické akademii sovětského ministerstva zahraničních věcí a později i na Moskevském státním institutu mezinárodních vztahů. V 70. letech Čubarjan analyzoval blíže vnější hospodářské vztahy Sovětského svazu, protože podle jeho názoru tvořily důležitou složku mírového soužití odlišných politických systémů. Soustředil se na Francii, Velkou Británii a Spojené státy. Leninské principy (př́stup $\mathrm{k}$ historii $\mathrm{z}$ pohledu revolucionáře) podle Čubarjana trvale zajištovaly kontinuitu sovětské diplomacie $v$ jejím mírovém úsilí. $V$ jejich duchu Moskva hájila plány na odzbrojení, mezinárodní snahy odmítající válku jako prostředek řešení mezinárodních vztahů, mezi jinými Ženevský protokol a Briand-Kellogův pakt,

40 Aleksandr Čubar'jan, Brestskij Mir (Moskva: Nauka, 1964); Aleksandr Čubar'jan, V. I. Lenin i formirovanije sovetskoj vnešnej politiki (Moskva: Nauka, 1972). 
a po porážce nacistického Německa také výzvu k ukončení kolonizace. ${ }^{41}$ To, že vedle mírového soužití byla leninským programem také méně vstřícná světová revoluce a že rapallská smlouva s Německem v roce 1922 vážně narušila rozvíjející se vztahy Moskvy se Západem, připustil teprve ve změněné atmosféře počátku 90. let. Tehdy také začal vysvětlovat světový meziválečný vývoj jako střet globálních trendů nacionalismu, internacionalismu a separatismu a varoval před pasivitou a ideologizací diplomacie. ${ }^{42}$ Pro Rusy citlivý Pakt Molotov-Ribbentrop, který ještě v roce 1964 hodnotil jako realistický, v roce 1993 zkritizoval jako protiprávní, amorální akt porcující svět v zájmu sovětské obrany na sféry vlivu. ${ }^{43}$

Zatím však Čubarjan v souladu se sovětskou politikou poloviny 60. let přesměroval svůj odborný zájem $\mathrm{k}$ možnostem přátelského soužití států s různými politickými režimy. Spojenectví Velké Británie a Spojených států amerických se Sovětským svazem během druhé světové války interpretoval jako doklad existence jejich určitého kooperativního potenciálu, ve velké trojce však omezeného na pasivní, a nikoliv kreativní fungování a tedy spějící ke studené válce. ${ }^{44}$ Tu podle jeho tehdejšího názoru modifikovala až komplexní proměna mezinárodní politiky po Karibské krizi a částečném zhroucení ideologie imperialismu. V nových podmínkách zbrojní rovnováhy sice podle Čubarjana sílily protisovětské ideologické útoky v nových oblastech (např. lidská práva), ale sovětský plán mírového soužití byl uznán za rozumnou formu mezinárodních vztahů. Myšlenka míru byla v tomto jeho pojetí neodmyslitelně spjata se samotným vznikem socialistického státu a byla od něho neoddělitelná; jejím prosazováním ovšem neměli být pracující celého světa připraveni o právo na sociální a národní osvobození. ${ }^{45}$ Př́ležitostná protikladnost mírového rozvoje světa nesměla podle něho zastínit skutečnost, že světové dějiny 20. století probíhají ve znaku socialistických idejí, navzdory šéfům NATO, západoněmeckým revanšistům, neofašistickým elementům v Itálii i snahám amerických militaristických a sionistických kruhů. S tímto výkladem se sovětský akademik prosadil díky vnitřní potřebě Svazu československo-sovětského prrátelství dokonce i do češtiny. Hlavními Čubarjanovými

${ }^{41}$ Aleksandr Čubar'jan, Mirnoje sosuščestvovanije. Teorija i praktika (Moskva: Politizdat, 1976).

42 Aleksandr Čubar'jan, „Jevropa 20-ch godov: novyje realii i tendencii razvitija“, in Jevropa meždu mirom i vojnoj 1918-1939, ed. Aleksandr Čubar'jan (Moskva: Nauka, 1992), 6-19.

${ }^{43}$ Klíčové pro novější Čubarjanova vyjádření byly trři mezinárodní konference završené knihou David Reynolds, Warren F. Kimball, A. O. Chubarian, eds., Allies at War. The Soviet, American and British Experience, 1939-1945 (London: Macmillan, 1994). Rusky Sojuzniki v vojne, 1941-1945 (Moskva: Nauka, 1995). Viz též Aleksandr Čubar'jan, ed., Sovetskaja vnešnjaja politika v retrospektive (Moskva: Nauka, 1993).

44 Čubar'jan, Vladimir Iljič Lenin i formirovanije sovetskoj vnešnej politiki.

45 Aleksandr Čubar'jan, ed., Problemy istorii meždunarodnych otnošenij i ideologičeskaja bor'ba. Sbornik statej. (Moskva: Nauka, 1976), 3-34. 
tématy 60. a 70. let byly otázky vzniku sovětské zahraniční politiky, vztahy Moskvy ke kapitalistickým státům, role socialistické spolupráce mezi státy, prŕćciny vzniku studené války a momenty revize sovětské ideologie. Stále výrazněji při jejich zkoumání hledal historický kontext tehdy aktuální sovětské zahraničněpolitické strategie, aby doložil její dlouhodobou kontinuitu, promyšlenost a zásadovost. ${ }^{46}$

Koncem sedmdesátých let Čubarjan často akcentoval otázku evropské bezpečnosti a postupně začal uvažovat o myšlence jednoty Evropy. Pod vlivem nastupujícího nového myšlení a Gorbačovovy teorie společného evropského domu ${ }^{47}$ sledoval historický vývoj uvažování o Evropě a porovnával jej s proměnami ruské idey. Myšlenka jednotné Evropy byla podle jeho názoru z roku 1983 mnohostranná a sporná od stř̌edověku a oslovila pouze některé intelektuály v meziválečné době, zatímco vlivnější regionální výklady dlouhodobě reprezentovaly konkurenční pangermánské, latinské, slovanské a balkánské projekty. Podle Čubarjana však bylo základním problémem Evropy rozdělení na Východ a Západ, které se ve 20. století proměnilo v neprátelské soužití dvou politicky, ekonomicky, ideově i společensky odlišných systémů. Přitom ani Rusko, ani Sovětský svaz nebyly, jak tvrdil v 80. letech, oddělitelné od evropské humanistické tradice, od aktuální a na obou stranách autentické potřeby snížit počty zbraní $v$ Evropě, zásobovat ji surovinami a úvěrovat její společný rozvoj. ${ }^{48}$ Nové Rusko mohlo podle Čubarjana vnést do Evropy vlastní pozitivní působení. Jeho zdroj Čubarjan určil v momentě rozpadu Sovětského svazu, kdy stejně jako mnozí ostatní hledal smysl existence samostatného ruského státu. Jako ruskou národní ideu vyzvedl toleranci a neopomněl zařadit pacifismus V. Malinovského mezi klasiky světových mírových hnutí. Vyzval k tomu, aby přehodnocování sovětských dějin probíhalo na základě historických faktů, a ne podle aktuální politické potřeby. Upozornil přitom na to, že národní zájmy by ideálně měly odpovídat zájmům lidstva, a bezpečnost jednoho by tedy neměla poškodit druhé. ${ }^{9}$

V novém tisíciletí Čubarjan-badatel opět souzněl s tónem zahraniční politiky své vlasti a snažil se blí̌ze nahlédnout ruské vnímání Evropy v kontextu

46 Aleksandr Čubar'jan, ed., Jevropa v meždunarodnych otnošenijach 1917-1939 (Moskva: Nauka, 1979); Alexandr Čubarjan, Uplatňování zásad mírového soužití států s rozdílným společenským zřizením (Praha: SČSP - Lidové nakladatelství, 1979).

${ }^{47}$ Michal Sergejevič Gorbačov, Přestavba a nové myšlení pro naši zemi a pro celý svět (Praha: Svoboda, 1987).

48 Čubar'jan, Jevropejskaja ideja v istorii; Aleksandr Čubar'jan, ed., Jevropa XX-go veka: problemy mira i bezopasnosti (Moskva: Izd-vo Meždunarodnyje otnošenija, 1985); Aleksandr Čubar'jan, ed., Velikij Oktjabr' i istoričeskij progress (Moskva: Nauka, 1987).

${ }^{49}$ Reynolds, Kimball, Chubarian, eds., Allies at War; Il'ja Gajduk, Natalija Jegorova a Aleksandr Čubar'jan, eds., Stalin i cholodnaja vojna (Moskva: Institut vseobščej istorii RAN, 1998); Aleksandr Čubar'jan, ed., Pacifizm v istorii. Idei i dviženija mira (Moskva: Institut vseobščej istorii RAN, 1998). 
úsilí o sjednocení kontinentu od francouzské revoluce. Takové plány označil za evropeismus a analogicky pak pro ruské snahy integrovat Evropu použil stejný termín, ruský evropeismus. Kromě tradičních slavjanofilských a západnických konceptů ruského poměru k Evropě přitom vyzdvihl bolševický koncept světové revoluce jako svého druhu zaujetí myšlenkou jednotné Evropy, byt jen takové, která měla vytvořit předpolí pro změnu světového řádu. Poměr nového Ruska k sjednocující se Evropě interpretoval Čubarjan s oporou v obrazu své vlasti jako civilizačního mostu mezi dvěma kontinenty. To nezměnil, ani když v souladu s dobovou diskusí uvažoval o eurasijském kontinentu, za jehož jednu část pokládal ruskou civilizaci. Podle jeho názoru se Eurasie vyznačovala specifickou vnitřní složitostí, komplikovanými vztahy mezi regiony a mimořádně silnými dopady globálních transformací. Rusko se podle něho do dynamických procesů zapojovalo jako zprostředkovatel. V letech 2003 až 2005 Čubarjan ovšem vyjadřoval víru, že tento most lze v daleké budoucnosti integrovat do Evropy, pakliže Moskva dokáže naplnit ekonomická kritéria Evropské unie, přizpůsobit se jejím ostatním, vyvíjejícím se normám a harmonizovat vztahy se všemi svými sousedy. Otázkou však podle Čubarjana zůstávalo, zda Evropa dokáže přijmout nový ruský, Vladimirem Putinem reprezentovaný, evropeismus opřený o důraz na ruskou státnost, ruské národní tradice a hodnoty. Takový tón, upozornil v závěru první dekády 21. století, konečně není cizí ani v Evropě přítomným zastáncům volnějšího spojení národních států. Naznačil, že právě tudy může vést ono očekávané přiblížení Ruska integrující se Evropě.50

S narůstajícím osvojováním sovětského vítězství ve druhé světové válce politickými představiteli nového Ruska Čubarjan některé své dřivější teze revidoval. Vyšel z konstatování, že výklad významu tohoto globálního konfliktu podléhá zkreslování na celém světě. $V$ postsovětském prostoru podle něho tento stav ještě zhoršují politizovaná hodnocení usilující o národní parcelaci společné minulosti a tedy i o potlačení myšlenky společného Vítězství. Ve zmíněné Tarleho cenou vyznamenané knize o letech 1939 až 1941 přiblížil vlastní společnosti sovětskou strategii před oficiálním vstupem Moskvy do války. Postup Moskvy, který je častým předmětem diskusí, vysvětlil s důrazem na vrcholnou zahraniční politiku Francie a Velké Británie. Podle něho byly zaskočeny prudkou akceschopností Německa a nechtěly se v prospěch svých východoevropských spojenců angažovat. Německo podle Čubarjana naopak správně pochopilo sovětský zájem o východní Evropu

50 Alexander Chubaryan, „Russian Europeanism: Essence and Opportunities. Europe - United Yet Divisible“, Russia in Global Affairs, č. 2 (2003), http://eng.globalaffairs.ru/number/n_865; Aleksandr Čubar'jan, Rossija v civilizacijnoj strukture jevrazijskogo kontinenta (Moskva: Nauka, 2004); Aleksandr Čubar'jan, Rossijskij Jevropeism (Moskva: Olma Press, 2006). 
(diskuse o průchodu sovětských vojsk) a nabídlo dohodu o jejím rozdělení. Proces sovětského rozhodování o způsobu naplnění smlouvy o neútočení a vymezení sfér vlivu podle Čubarjana probíhal pod německým tlakem. Stalin intenzivně konzultoval s vedoucími činiteli sovětské diplomacie, komisariátů vnitra a obrany. V nezvratně se měnící situaci usiloval o takové řešení, které by zajistilo bezpečí jeho země a nenarušilo její vnitřní integritu nevysvětlitelnou změnou sovětského doktrinárního a ideologického postoje. To se mu podle Čubarjana povedlo, když dokázal časově oddělit obsazení Polska Rudou armádou od německého útoku. Demarkační linie na hranici označené dříve lordem Courzonem jako hranice etnik a systematická práce na inkorporaci Sověty získaných území jako západních oblastí Běloruska a Ukrajiny pak umožnily Stalinovi oddělit vlastní akce od německé agrese také tematicky. Díky tomu, konstatuje Čubarjan, nebyla sovětská neutralita v zahájeném válečném konfliktu navenek zpochybněna a současně byla veřejná část sovětsko-německé dohody přijatelně zdůvodněna i sovětské veřejnosti. Pokud jde o Pobaltí, připomněl Čubarjan autoritářský charakter tamních režimů, které podle něho odcizily politické vedení od široké veřejnosti a pronásledovaly levici. Ta proto podle něho podporovala spojenectví se Sověty a zasloužila se o to, že zákonodárné sbory všech tří pobaltských zemí přijaly po volbách provedených podle sovětského vzoru usnesení o připojení k Sovětskému svazu. Čubarjan upozorňuje, že řešení záležitostí jiných států velmocemi bylo tehdy běžnou praxí. V situaci, kdy se Francie a Británie rozhodly nepodpořit pobaltskou samostatnost, proto podle něho neexistovalo jiné východisko. Naprríklad pokusy pobaltských vlád koordinovat společný postup na podzim 1939 komentuje pouze jako naivní snahu, o níž si přece musely být vědomy, že vyvolá negativní sovětskou reakci. Charakteristický postoj zaujímá Čubarjan také $k$ těm výzkumům současných pobaltských a ruských historiků, kteří situaci popisují jako sovětskou vojenskou převahou vynucené kroky ústící v sovětskou okupaci Pobaltí. Podle Čubarjanova názoru přitom nelze vstup Litvy, Lotyšska a Estonska do Sovětského svazu chápat jako okupaci už jen proto, že tamní obyvatelé získali stejná občanská práva, jaká byla obvyklá v ostatních částech Sovětského svazu. Čubarjan připouští jediný negativní rys sovětské akce v Pobaltí: navazující represi. I tu ovšem chápe jako obvyklou v rámci sovětské společnosti. ${ }^{51}$ Neutralita a jistá garance zajištění bezpečí sovětského státu, o něž sovětská diplomacie v konfliktu imperialistických států $v$ souladu s komunistickou ideologií původně skutečně usilovala, vzaly za své teprve Stalinovým rozhodnutím stvrdit dodatečnou Dohodu

${ }^{51}$ Srov. Irmina Matonyte, „The Elites' Games in the Field of Memory: Insight from Lithuania“, in History, Memory and Politics in Central and Eastern Europe. Memory Games, ed. Georges Mink a Laure Neumayer (New York: Palgrave Macmillan, 2013), 105-20. 
o spolupráci s Hitlerem, tvrdí Čubarjan. Vnímal-li Stalin, že Hitler považuje sovětsko-německé spojenectví pouze za dočasný taktický manévr, není podle Čubarjana jasné. Odmítnout však podle jeho názoru lze tvrzení Viktora Suvorova, že by byl Stalin připravoval válku proti Hitlerovi a ten ho útokem v červnu 1941 předběhl. ${ }^{52}$ Ve skutečnosti, tvrdí Čubarjan, se Sovětský svaz Stalinovým přičiněním stal německým rukojmím. Stalin podle něho uvěřil německým slibům a lžím, ztratil smysl pro realitu i míru a byl ochoten nejen revidovat sovětskou zahraniční politiku, ale také ideologii. Na přelomu let 1940 a 1941, kdy si Stalin začal nebezpečí uvědomovat, Čubarjan už nenalézá jiné řešení situace než smlouvou s Japonskem realizované rozhodnutí zabránit válce na dvou frontách a propagandistickým obratem zahájené posilování sovětského odstrašovacího potenciálu. Tato opatření, stejně jako ekonomický appeasement ve snaze maximálně oddálit střetnutí s Německem, aplikoval podle něho Stalin správně. Ve složité mezinárodní situaci mu nezbývalo než jen čekat: „Berlín ovládala euforie z nového grandiózního vojenského pochodu, který měl svrhnout bolševismus, pokořit Rusko a poté uštědřit poslední ránu Velké Británii. [...] A hlavní osobnost v Kremlu [...] si kladla stále tytéž otázky - byla-li jeho volba v srpnu a záŕí 1939 správná a zdali skutečně nemohl přehrát Hitlera. “53

Čubarjan tedy nahlíží jednání Stalina kriticky a označuje ho dokonce za protipól pacifismu a humanismu. $V$ diskusích, které vlivem snahy ruských prezidentů první dekády 21. století kodifikovat Vítězství ve Velké vlastenecké válce jako úhelný kámen národní historie ovládly ruský veřejný prostor, mu však důraz na údajně bezvýchodnou mezinárodní situaci umožňuje vyhnout se jednoznačnému soudu o Stalinovi. Čubarjan vyjádřil určité pochopení pro složitost jeho rozhodování a podtrhl, že charakter stalinismu neměl nic společného s hrdinstvím lidu, který po dvacet let prokazoval nezměrnou vůli i sílu modernizovat a ochránit vlast. Znovu se tak vrátil ke starému triku sovětské diplomacie, která „lid“ uměle oddělovala od jeho vedení všude tam, kde jí politická elita nebyla nakloněna, a podpořil nový prezidentský výklad stalinského teroru jako ceny zaplacené předky za obrovský vzestup Ruska a porážku hlavního dějinného zla - fašismu.

\section{Organizace a financování vědy}

Do funkce ředitele Institutu všeobecných dějin Akademie věd Sovětského svazu, resp. Ruské akademie věd byl Čubarjan svými kolegy zvolen v roce 1988, poté co

\footnotetext{
52 Česky vyšla Suvorovova práce jako Viktor Suvorov, Ledoborec. Všechno bylo jinak aneb kdo začal druhou světovou válku? (Praha: Naše vojsko, 1995).

53 Čubar'jan, Kanun tragedii, 463.
} 
přes deset let úspěšně vedl nejprve jeho sektor a potom oddělení dějin mezinárodních vztahů. V turbulentní atmosféře ideologických změn a navazujících reforem prokázal nesporné organizační dovednosti i obdivuhodnou schopnost zajistit chod svěřené instituce. Tváří v tvář proměně paradigmat, metod historické práce, př́livu výsledků zahraniční vědy a celospolečenské neochotě čekat na nově tlumočenou historii čelil ztrátě jistoty velkorysého finančního krytí bádání ze strany státu a s ní spojeným personálním změnám. Dokázal si však zachovat autoritu, svými mezinárodními zkušenostmi zjevně inspirovaný nadhled i relativně přesnou představu o činnosti svých kolegů a při každoročním hodnocení jejich výsledků a budoucích možností uměl nalézat slova chvály a nabízet perspektivu. Jeho podřízení se od roku 1989, kdy namísto vědeckých pracovišt začal stát financovat konkrétní projekty, pohybovali v politicky poutavých tématech 20 . století a on je podporoval ve spolupráci s domácími archivy i zahraničními partnery a vyzýval je k ostražitosti vůči politické utilitaritě. Přehodnocování sovětských dějin mělo podle něho probíhat na základě historických fakt, nikoliv podle aktuální politické potřeby. Problém reformy financování vědy ho současně přivedl blíže k ruským politikům, do prezidentské Rady pro vědu, vzdělávání a technologie, kde usiloval o alespoň minimální respekt $\mathrm{k}$ humanitním vědám a upozorňoval, že poskytované prostředky pokrývají nízké platy jeho podř́zených nanejvýš ze sedmdesáti procent. ${ }^{54}$

Chybějící finance dokázal Čubarjan zajistit z ciziny, která dychtivě reagovala na ruskou archivní revoluci a Čubarjana vnímala jako vlivného partnera. Již od sedmdesátých let si totiž díky vlastnímu zahraničněpoliticky orientovanému výzkumu, znalosti anglického i francouzského jazyka a politické spolehlivosti systematicky budoval kontakty v mnoha západních zemích. Ty mu nejen dovolily získat funkci v národní odbočce Mezinárodního výboru historických věd, ale i zajištovaly, a to ještě $\mathrm{v}$ dobách platnosti mimořádně př́ísných omezení pro vycestování ze Sovětského svazu, možnost konfrontovat doma dostupné prameny se studiem v západních archivech a knihovnách. V 90 . letech se právě tudy otevřela Čubarjanova cesta k prudce se rozvíjející spolupráci ruských historiků se západními vědci a zejména k projektům mezinárodní vědecké spolupráce. Na té se Čubarjan od svého zvolení členem Rady Mezinárodního výboru historických věd na madridském kongresu v roce 1995 až po kongres v Oslo v roce 2000 aktivně podílel. ${ }^{55}$ Za ruskou stranu byl partnerem mnoha projektů, které západní instituce v Rusku

54 T. S. Trubinova, „Godičnoje sobranije Akademii nauk SSSR“, Novaja i novejšaja istorija 32, č. 4 (1989): 226-28; „O rabote instituta vseobščej istorii RAN“, Novaja i novejšaja istorija 38, č. 4 (1995): 3-11.

55 S. L. Tichvinskij, „Sozdavaja atmosferu meždunarodnogo naučnogo sotrudničestva (Akademik A. O. Čubar'jan na kongressach MKIN)“, in Istoričeskaja nauka na rubeže vekov, ed. A. A. Fursenko (Moskva: Nauka, 2001), 18-27. 
spolufinancovaly; mimo jiné zaštítil přípravu sedmi svazků dokumentů z archivu Komunistické internacionály i digitalizaci jeho fondů. ${ }^{56}$ Dalších výzkumných úkolů se dotkl z pozice předsedy bilaterálních komisí ruských historiků s kolegy z Litvy, Německa, Rakouska, Rumunska a Ukrajiny nebo jako garant spolupráce s konkrétními zahraničními institucemi. ${ }^{57}$

Zkušenosti z tak intenzivního zapojení do mezinárodní spolupráce se snaží Čubarjan zúročit i dnes. Zatímco dříve však motivoval své podřízené $\mathrm{k}$ utváření tezí v průběhu mezinárodního výzkumu, dnes při vlastní práci spíše dává přednost tomu, aby zahraniční experti z Francie, Velké Británie, Německa a Spojených států amerických pouze ve vztahu ke světovým trendům hodnotili aktuálnost ruskými historiky domácím grantovým agenturám nabídnutých projektů. $\mathrm{V}$ době, kdy Rusko (na vlně zděšení své politické elity z údajně Západem rozpoutaných oranžových revolucí) chce znovu samo plně financovat vlastní historický výzkum, Čubarjan nestojí podle svých slov o to, aby jako dřive docházelo k mrhání prostředků na pouze formálně do projektů zapojené zahraniční vědce. Tím chce řídit také své působení v dozorčí radě vládou nedávno zřízené tř̌etí ruské grantové agentury, ${ }^{58}$ kam ho přizval pobočník prezidenta Putina, Andrej Fursenko. „Všichni si pamatují na konkurz megagrantů, v jehož rámci se k nám zvali zahraniční vědci [...] Jak se ukázalo, [...] zejména $\mathrm{v}$ humanitních vědách bylo obtížné najít člověka ochotného přijet do Ruska na šest měsíců pracovat,“ dokládá oprávněnost svého názoru Čubarjan. Nová agentura, Ruský vědecký fond (Rossijskij naučnyj fond), má oproti již existujícím dvěma agenturám podle Čubarjana více hájit komplexní př́istup k rozvoji ruské vědy a přidělovat finanční prostředky na základě výběrových řízení z projektů předložených ruskými badateli. Ǩeditel Institutu všeobecných dějin Ruské akademie věd si od toho slibuje větší pozornost ke v Rusku podle jeho názoru doposud přehlíženým humanitním a sociálním vědám. ${ }^{59}$

56 Ja. S. Drabkin et al., ed., Komintern i ideja mirovoj revoljucii: Dokumenty (Moskva: Nauka, 1998); M. M. Narinskij, K. M. Anderson a A. O. Čubar'jan, eds., Komintern i Vtoraja mirovaja vojna. V 2 častjach (Moskva: Pamjatniki istoričeskoj mysli, 1994, 1998).

57 Napřr. rusko-bělorusko-ukrajinský akademický projekt A. A. Kovalenja, V. A. Smolij, A. O. Čubar jan, eds., 1941 god: strana v ogne: istoriko-dokumental'noje izdanije: $v$ dvuch knigach (Moskva: Olma media grupp, 2011).

58 V Rusku již od první poloviny devadesátých let pracuje prezidentským dekretem zřízená samosprávná nezisková státní organizace Ruský státní fond základního výzkumu (Rossijskij fond fundamental'nych issledovanij, RFFI), www.rfbr.ru, a vládním nařízením vytvořená státní příspěvková organizace Ruský humanitární vědecký fond (Rossijskij gumanitarnyj naučnyj fond, RGNF), www.rfh.ru.

59 Rozhovor Niny Šatalovové s Alexandrem Čubarjanem „Ujti ot povtorenij. Novyj fond pomožet v opredelenii prioritetov“, Poisk, 24. března 2014, www.poisknews.ru/theme/science-politics/9619. 


\section{Organizace výuky dějin}

Ačkoliv Čubarjanovy pedagogické zkušenosti vznikaly ve vysokoškolském prostředí, v polovině 90 . let se zapojil do probíhající reformy ruského základního vzdělávání a jako rektor Státní univerzity humanitních věd, která s oporou v akademii věd usiluje o maximální sblížení studentů s aktuálními výzkumnými prioritami, zaštítil práce na novém komplexu dějepisných učebnic a metodických materiálů pro 5. až 11 . tř́ídy základních škol. ${ }^{60}$ Zapojil se také do řešení několika encyklopedických projektů. ${ }^{61}$

$S$ novým tisíciletím, v němž prezident Putin opakovaně deklaroval svưj zájem ovlivnit obsah dějepisu v prospěch vlastní interpretace jednotící ruské národní idey, se Čubarjan v debatě o výuce ruských dějin na základních a středních školách angažoval stále více. Když Putin v roce 2004 reorganizoval prezidentskou Radu pro vědu, technologie a vzdělávání a oslabil vliv akademiků na její fungování (do srpna 2004 měla Rada 22 členů, $\mathrm{z}$ toho 20 pracovalo v Akademii věd; po Putinově zásahu se tento poměr změnil na $33: 24$ ), Čubarjan zůstal její součástí. ${ }^{62}$ Užitečným se stal především po fiasku Medvedevova úvodního experimentu prosazujícího v letech 2008 a 2009 ruskou politickou špičkou inscenovaný výklad nedávné národní minulosti kombinací v mnohém skandálního souboru Filippovových a Danilinových učebnic a metodických textů se zř́zením prezidentské Komise na obranu proti pokusům padělat dějiny na úkor Ruska. Zatímco mezi historiky neznámý Filippov a prominent Danilin nedokázali své teze veřejně obhájit jinak než odkazy na vůli ruských mocných, Čubarjan vnesl do politických debat o ruské minulosti smírlivý tón a schopnost nacházet na kritiku vědecky relevantní odpovědi. Besedující často výrazně odborně převyšuje; vždyt’ jeho partnery bývají až př́liš často $\mathrm{z}$ titulu svých řídících funkcí v nejrůznějších nevládních historických společnostech straníci Jednotného Ruska, např́klad ministr kultury a předseda Ruské vojensko-historické společnosti Vladimir Medinskij nebo estrádní umělkyně, šéfka aparátu Státní dumy a členka rady Ruské historické společnosti Džachan Pollyjeva. V roce 2011 vyšlo pod Čubarjanovým vedením páté, doplněné vydání

${ }^{60}$ Diskuse o proměně ruského historického vzdělávání 90 . let 20. století zachycuje práce Kaplan, Pinchas, Ermolaeva, The Teaching of History in Contemporary Russia. Viz také Ben Eklof, Larry E. Holmes, Vera Kaplan, eds. Educational Reform in Post-Soviet Russia: Legacies and Prospects (New York: Frank Cass, 2005).

${ }^{61}$ Nejnověji viz Michail Mjagkov, Aleksandr Čubar'jan a Jurij Nikiforov, Velikaja Otečestvennaja vojna. Encyklopedija (Moskva: Olma media grupp, 2015). Čubarjan řídil také kolektiv pracovníků IVI RAN při práci na Rossijskaja istoričeskaja encyklopedija (Moskva: Olma media grupp, 2015).

62 Sovet po nauke, technologijam i obrazovaniju, http://ps.1september.ru/article.php?ID=200507205. 
učebnice ruských dějin od 20. do 21. století. ${ }^{63}$ Odbornost, zdůrazněná uvedeným kontextem, Čubarjanovi nijak překvapivě otevírá př́stup do vedoucích pozic $\mathrm{v}$ dalších nově se objevujících příslušně zaměřených společenských i státních organizacích. Čubarjan tak mimo své ředitelské pozice v Institutu všeobecné historie a vedle funkce prezidenta (před tím rektora) Státní univerzity humanitních věd dnes působí také v uvedené Prezidentské radě pro vědu, vzdělávání a technologie, spolupředsedá Akademické vzdělávací organizaci, předsedá všeruské společenské organizaci Asociace učitelů historie a společenských věd a je prezidentem Mezinárodní asociace historických fakult zemí Společenství nezávislých států.

Rok 2012, kdy byl Medveděvův neúspěšný historicko-vzdělávací projekt završen zrušením Komise na obranu proti pokusům padělat dějiny, byl v Rusku vyhlášen rokem historie. Čubarjan během něho plynule vyměnil členství ve zrušené komisi za post vědeckého ředitele připravované Ruské historické společnosti a spolu s předsedou této formálně nezávislé nevládní organizace, někdejším šéfem ruské vládní i prezidentské administrativy a současným předsedou dolní komory ruského parlamentu, Sergejem Naryškinem, začal připravovat koncepci jednotného standardu ruských historických učebnic. Cílem, který v rozhovorech obhajoval i prezident Putin, bylo vyloučit možnost existence protikladných výkladů národní minulosti a zaměnit nepřehledné desítky povolených dějepisných výukových textů jednotným chronologicky správným konceptem, který bude obsahovat oficiální hodnocení historických událostí a stane se základem jednotných učebních a metodických materiálů pro všechny ruské základní školy.

Čubarjanova cesta $\mathrm{k}$ tomuto cíli začala již v roce 2011, kdy se aktivně zapojil do př́ipravy a průběhu Prvního sjezdu ruských učitelů dějepisu a společenských věd v Moskvě. V prosinci téhož roku ho spojení s Naryškinem vyneslo mezi členy dozorčí rady právě šéfem Ruské dumy vedené neziskové organizace Fond soudobých dějin založené v červnu 2008. Dva měsíce po Čubarjanově nástupu do této funkce došlo k propojení fondu s historicko-filologickým sektorem Ruské akademie věd, které pak na květnovém valném shromáždění vědců prezentoval jejich šéf Anatolij Derevjanko jako logický výsledek úctyhodných vědeckých, vydavatelských a vědecko-organizačních počinů fondu. $\mathrm{O}$ měsíc později byla institucionální rošáda $\mathrm{z}$ iniciativy více než třicítky galerií, univerzit, společenských, vědeckých i státních organizací završena založením Ruské historické společnosti. Ta znovu svým předsedou zvolila vzděláním ekonoma Sergeje Naryškina a jako spolupředsedy také akademiky Anatolije Derevjanka, Alexandra Čubarjana a rektora

63 Aleksandr Čubar'jan, Aleksandr Danilov a Jefim Pivovar, Istorija Rossii XX - načalo XXI veka. 11 klass. Učebnik. Profil'nyj i bazovyj urovni (Moskva: Prosveščenije, 2011). 
MGIMO Anatolije Torkunova. Vzápětí se přihlásila k tradici carské ruské historické společnosti z konce 19. století a vyzvala prezidenta Putina, aby stanul v čele její dozorčí rady. ${ }^{64}$

Prostředkem k vytvoření oficiálního školního výkladu ruských dějin se stala pětašedesátistránková Koncepce nového metodicko-vzdělávacího komplexu domácí historie a v ní obsažený historicko-kulturní standard diktující základní hodnocení klíčových událostí minulosti, výklad termínů, personálií i seznam obtížných a ve společnosti dosud sporných historických otázek. Uvádí hlavní metody, které jsou při výuce dějepisu v ruské základní škole př́pustné, a určuje jak tematicky rozložit výuku do jednotlivých ročníků. Předpokládá, že v souladu s jeho zněním budou upraveny i jednotné státní zkoušky z dějepisu a učitelé absolvují kurzy zvyšující daným směrem jejich kvalifikaci. ${ }^{65}$ Kritici celé koncepce od počátku protestují proti absolutizaci jednoho výkladu a upozorňují na ústavní garanci názorové plurality a svobody. Také zástupci neruských republik se stavějí proti nahrazování vlastní interpretace minulosti rusifikovaným výkladem. Čubarjan odpovídá odkazy na přání učitelů dějepisu vyjádřená na jejich prvním (2011) a druhém (2012) sjezdu. Tvrdí, že sama existence mnoha desítek dějepisných učebnic ve skutečnosti nedovoluje učitelům už pro své množství seznámit se $s$ různými náhledy na historické události a nutí je v jejich výkladu podléhat zkreslením. ${ }^{66}$

Historik Andrej Zubov v diskusi, kterou s Čubarjanem v listopadu 2013 o koncepci vedl, vyjádřil přesvědčení, že skrze ni pokračuje vytváření jednotné ideologie v oblasti historie, která Rusko fakticky vrací do sovětské totalitární doby, kdy učebnice dějepisu diktoval primát ideologické jednoty obrovského státu a vše, co mu odporovalo - jednotlivci, nebo jiné státy - bylo označováno za nepřátelské. Podle Zubovova názoru nesmí profesionál a občan dnešní ruské společnosti přestat připomínat, že neexistují nesprávné prŕstupy a že rozdílné názory je třeba tříbit diskusí. Podle Čubarjana je sice třeba občany vzdělávat a sbližovat s demokratickými názory, je ale také nutné vycházet $\mathrm{z}$ reality, v níž žijeme. Koncepce, tvrdí Čubarjan, různé názory odráží a pomáhá se v nich občanům zorientovat. ${ }^{67}$

${ }^{64}$ Lenta novostej. Fond sovremennoj istorii, http://mhf.su/news/news.

${ }^{65}$ Koncepcija novogo učebno-metodičeskogo kompleksa po otečestvennoj istorii.

66 Ol'ga Daškovskaja, „Učiteljam ne chvatajet znanij, učebnikam - prostoty“, Pervoje sentjabrja, č. 20 (2010), http://ps.1september.ru/view_article.php?ID=201002004. Viz také rozhovor Daškovské s Alexandrem Čubarjanem „Istorija ne dolžna byt' založnicej politiki“, Pervoje sentjabrja, č. 8 (2011), http://ps.1september.ru/article.php?ID=201100803. Viz dále Ol'ga Daškovskaja, „Učebnik bystrogo prigotovlenija“, Pervoje sentjabrja, č. 12 (2013), http://ps.1september.ru/view_article.php?ID=201301204.

67 Debata Alexandra Oganoviče Čubarjana s Andrejem Zubovem „Jedinyj učebnik dlja razorvannogo obščestva“, Novoje vremja, 26. listopadu 2013. 
Pokud jde o konkrétní obsah, za nejspornější je považován výklad vývoje Ruska od počátku 20. století, který koncepce plánuje pro desátou a jedenáctou tř́du ruských škol. Zatímco podle Čubarjana není sovětská epocha jen érou gulagu, protože v dobách prvních pětiletek v sobě stát našel sílu k prudkému vzestupu, Zubov je přesvědčen, že tehdy nešlo o nalezení síly $\mathrm{k}$ pokroku státem, ale o proměnu vyždímanou Stalinem z milionů umírajících a vězněných lidí. Celá koncepce podle Zubova ignoruje člověka; je napsána nikoliv v zájmu vzdělání, ale v prospěch ideologického posílení současného státu v prostalinském duchu, sovětským propagandistickým jazykem. Čubarjan právo státu posílit výukou dějin vlastní pozici obhajuje a trvá na tom, že naučit děti ctít zásluhy ruských seniorů patř́ $\mathrm{k}$ jeho základním povinnostem. Popírá rovněž, že by koncepce žáky nebo učitele manipulovala, a snaží se doložit, že odlišné názory na konkrétní otázky byly jeho zásluhou integrovány. Jak však v rozhovoru Zubov několikrát naznačuje, to, co Čubarjan podle svých slov ve znění prosadil, se do finální podoby koncepce nepromítlo. ${ }^{68}$

\section{Závěr}

Každá ze tř́i nastíněných oblastí (věda, výuka, politika), v nichž se odehrává přehodnocení ruského vztahu k nedávné minulosti, má vlastní pravidla, metodologii a plní jiné společenské role. Představa, že původní informační vakuum, které vzniklo diskreditací sovětské historiografie, bude zaplněno objektivnějším pohledem s pomocí odtajněných dokumentů, se ukázala jako značně zjednodušující. Změna interpretace sovětských resp. ruských dějin nebyla a není ani zdaleka jednoznačná; probíhá v několika fázích a svými strategiemi se na ní podílejí různě motivovaní aktéři. Vědecké poznání minulosti je cílem jen části těchto aktérů. Ostatní skupiny do debaty o sovětské historii vstupují, protože jejím prostřednictvím mají možnost ovlivnit podobu společenských hodnot a pravidel. Debata o minulosti v současném Rusku zároveň slouží nové politické moci jako legitimizační a integrační nástroj, který dnešku poskytuje smysl.

Majoritní veřejná diskuse sovětské minulosti se v současném Rusku odehrává jako druh mediální zábavy a Alexandr Čubarjan patří k nemnoha historikům, kteří v ní mají reprezentovat elitní vědu. Patří současně k pamětníkům, kteří dokázali ve státní historické politice sovětské i postsovětské éry úspěšně nalézat uplatnění. Je symptomatické, že z mladších generací preferuje ruská státní moc v historickém diskurzu profesionální politiky, ekonomy nebo právníky. Jako nejvýraznější výsledek takového průběhu diskurzu vystupuje konstrukce sovětského vítězství

68 Ibid. 
ve Velké vlastenecké válce v květnu 1945 jako nejvýraznější opory dnešní ruské identity. Prizmatem tohoto mezníku jsou nahlíženy předcházející i navazující události. Geograficky je zdůrazněn prostor, kde sovětská vojska válčila. Ve vztahu ke konsolidaci poválečného světa je pak vyzdvižena vděčnost osvobozených společností za odstranění fašistického zla. Sázka na zjednodušující rovnici boje dobra se zlem a identifikace současného Ruska s obětavým sovětským vítězem posiluje současným ruským vedením prosazovanou politiku paměti.

Míra, jakou politizaci historie podléhají ruští historici, je individuální a souvisí s jejich osobními zkušenostmi a oborovou specializací. Alexandr Čubarjan nepřipouští zpochybnění správnosti sovětské vnější strategie. Současně popírá existenci protichůdných autentických zájmů jiných států. Množství a charakter výhrad, které Čubarjan vznáší proti výsledkům a metodám cizí vědy, přitom ukazuje, že právě sovětská zahraniční politika patří v dnešním Rusku ke klíčové části sovětského dědictví. 